\title{
PRODUCTIVITY OF SEED POTATO AT SPRING AND SUMMER PLANTING WITH FRESHLY-COLLECTED TUBERS IN THE CONDITIONS OF THE SOUTH OF UKRAINE
}

\section{Boyarkina L. V.}

\section{INTRODUCTION}

Potatoes have a prolonged vegetation period, during which it assimilates significantly more nutrients from the soil than other crops. On the formation of 10 tons of potatoes it is required $40-60 \mathrm{~kg}$ of nitrogen, 15-20 of phosphorus, 70-90 of potassium, 20-40 of sulfur, 10-25 of magnesium, 25-50 kg of calcium and a number of microelements. With a crop of $20 \mathrm{t} / \mathrm{ha}$ with the corresponding number of leafy tops it uptakes from the soil about $100 \mathrm{~kg}$ of nitrogen, 30 of phosphorus and $140 \mathrm{~kg}$ of potassium. It should be mentioned that the root system of potato can absorb from the soil higher amounts of potassium than other crops ${ }^{1}$.

The use of mineral fertilizers can create the optimum ratio between nitrogen, phosphorus, potassium and other necessary nutrients on all types of soils. At the present stage, combined complex mixtures of fertilizers are mainly used: nitrophoska, ammonium phosphate, amophos, etc. An important task in the field of potato growing is the development of methods for improving the effectiveness of mineral fertilizers with reduced norms of their application.

In the improvement of the effectiveness of mineral fertilizers, an important role is also played by the way of their application to the soil $^{2}$. This can be achieved by applying mineral fertilizers locally. With the local method of fertilizing, the transfer of nutrients of fertilizers in

1 Базалій В.В., Зінченко О.І., Лавриненко Ю.О., Салатенко В.Н., Коковіхін С.В., Домарацький Є.О. Рослинництво : Підручник; за ред. В.В. Базалія, О.І. Зінченка, Ю.О. Лавриненка. Херсон : Грінь Д.С., 2014. 461 с.: іл.

2 Бондарчук А.А. Наукові основи насінництва картоплі в Україні : монографія. Біла Церква, 2010. 400 с. 
the soil into inaccessible forms for plants is also significantly reduced $^{3,4}$.

Researches conducted by scientists in different soil and climatic conditions prove that fertilizers contribute to the increase of yield, simultaneously improving or decreasing the quality of tubers. It depends on a number of factors: doses, ratios, forms, terms and methods of fertilization, weather conditions, etc. Large share of mineral fertilizers expenditures in the structure of production cost of potatoes (19-21\%) requires constant seeking for new ways making production cheaper. It is known that the local application of mineral fertilizers with a dose, reduced by a half, provides obtaining almost the same yield of potatoes, as at the full dose of scattered fertilizers applied $^{5}$.

The Institute of Potato growing of NAAS developed resourcesaving technology of potato cultivation. An important link of this technology is the use of optimum resource-saving system of potato fertilization. It is known that the rational system of fertilization provides not only the increase in yield and improvement of its quality, but also promotes fertility preservation of soil. Science and practice of fertilizers application showed that the return from them depends not only on the norm and singing ratio between the main elements, but also on the methods of their application. Technological regulations of the resource-saving technology of potato growing are provided by the local application of mineral fertilizers at planting of tubers ${ }^{6,7}$.

3 Вильдфлуш И. Р. Локальное внесение удобрений - одно из главных средств рационального и экономного использования минеральных удобрений. Агрохимия. 1996. Вып. 10. С. 132-141.

${ }^{4}$ Власенко М. Ю., Руденко Г. С. Вплив різних норм мінеральних добрив на вміст на врожайність і якість нових сортів картоплі. Картоплярство. К. : “Урожай”, 1987. Вип. 18. С. 40-42.

5 Патика В. П., Макаренко Н. А., Моклячук Л. І. та ін. Агроекологічна оцінка мінеральних добрив і пестицидів: монографія; за ред. В. П. Патики. К.: Основа, 2005. 300 c.

${ }^{6}$ Технологічний регламент вирощування картоплі: рек. : Мінагрополітики України, Ін-т картоплярства УААН. Немішаєве, 2007. 15 с.

${ }^{7}$ Кубарева Л. С. Локальное внесение удобрений. Бюл. ВИУА. 1980. № 53. C. $13-15$. 
One of the conditions for obtaining high yields of seed potato is the use of appropriate plant density per unit area. The average planting density of seed potato depends on the mass of planting material, ripeness of variety, destination of plantings and humidification of soil. In the Steppe zone on irrigation it is recommended to plant the tubers with weight of $50-80 \mathrm{~g}$ with a density of $50-55$ thousand/ha ${ }^{8}$.

By the results of previous studies, it was determined that the optimum density of the plant standing, which provides the maximum yield, is individual for the each separately taken from variety ${ }^{9}$.

The basis of any crop cultivation technology is the fertilization system, adapted to local soil and climatic conditions. Therefore, the question of determination of optimal norms of mineral fertilizers and planting density of tubers for the conditions of the South of Ukraine remains of current importance.

\section{Productivity of seed potato at early harvesting depending on the norms of fertilizers and planting density}

The researches of the Institute of Irrigated Agriculture of NAAS proved high efficiency of application of mineral fertilizers under the potato locally with the ridge planting on the depth of $15-18 \mathrm{~cm}$. This method provided the best productivity of the plants in the biological maturity and at the early harvesting at the application of a low norm of mineral fertilizers $-\mathrm{N}_{60} \mathrm{P}_{60} \mathrm{~K}_{60}$. The question of determining the optimal norms of mineral fertilizers application at their local use at planting remains unexplored. Special interest was to the determination of the optimum conditions of the potato plants nutrition in the conjunction with the tubers planting density. In this regard, in 20062008, the double-factored field experiment was carried out according to the scheme, specified in the tables.

The analysis of three-year plant growth data showed a tendency to the decrease of the number of stems with a higher density of planting. Thus, at the density of planting of 42.8 thousand of tubers/ha, on the average by the factor, the number of stems per one bush during the

\footnotetext{
${ }^{8}$ Картопля: сортозаміна і сортооновлення. Пропозиція. 2017. № 1. С. 126-128.

9 Куценко В.С. Формування оптимальної густоти насаджень картоплі різного господарського призначення : Картоплярство. К., 1997. Вип. 27. С. 34. C. 39 .
} 
flowering period was 2.5 pcs., at the density of 57.1 thousand 2.4 pcs., at the density of 71.4 thousand -2.3 stems per one bush (Table.1). This dependence is confirmed by the inversely proportional pair correlation coefficient $(r=-0.887 \pm 0.128)$. The degree of the closeness of the relationship between the investigated factors and the indicator of the number of stems per one bush is strong $(\mathrm{R}=0.890)$. Multiple determination coefficient $\left(\mathrm{R}^{2}=0.791\right)$ indicates that the variation of the number of stems by $79.1 \%$ depends on the influence of factors that were explored.

Table 1

The number of stems of potato depending on the nutrition level and the density of planting

\begin{tabular}{|l|l|c|c|}
\hline \multirow{3}{*}{$\begin{array}{c}\text { The density } \\
\text { of planting, } \\
\text { thsd. pcs/ha }\end{array}$} & Nutrition background & \multicolumn{2}{|c|}{ The number of stems } \\
\cline { 3 - 4 } & & $\begin{array}{c}\text { thousand } \\
\text { pcs/ha }\end{array}$ & pc/bush \\
\hline \multirow{4}{*}{42.8} & Without fertilizers & 102.5 & 2.5 \\
\cline { 2 - 4 } & $\mathrm{N}_{30} \mathrm{P}_{30} \mathrm{~K}_{30}$ & 103.2 & 2.5 \\
\cline { 2 - 4 } & $\mathrm{N}_{60} \mathrm{P}_{60} \mathrm{~K}_{60}$ & 105.3 & 2.6 \\
\cline { 2 - 4 } & $\mathrm{N}_{90} \mathrm{P}_{90} \mathrm{~K}_{90}$ & 105.2 & 2.6 \\
\cline { 2 - 4 } & $\mathrm{N}_{120} \mathrm{P}_{120} \mathrm{~K}_{120}$ & 99.0 & 2.4 \\
\hline \multirow{5}{*}{57.1} & $\mathrm{Without} \mathrm{fertilizers}_{5}$ & 130.7 & 2.4 \\
\cline { 2 - 4 } & $\mathrm{N}_{30} \mathrm{P}_{30} \mathrm{~K}_{30}$ & 128.0 & 2.4 \\
\cline { 2 - 4 } & $\mathrm{N}_{60} \mathrm{P}_{60} \mathrm{~K}_{60}$ & 132.6 & 2.4 \\
\cline { 2 - 4 } & $\mathrm{N}_{90} \mathrm{P}_{90} \mathrm{~K}_{90}$ & 129.5 & 2.4 \\
\cline { 2 - 4 } & $\mathrm{N}_{120} \mathrm{P}_{120} \mathrm{~K}_{120}$ & 137.0 & 2.5 \\
\hline & $\mathrm{Without} \mathrm{fertilizers}_{7}$ & 148.5 & 2.2 \\
\cline { 2 - 4 } & $\mathrm{N}_{30} \mathrm{P}_{30} \mathrm{~K}_{30}$ & 156.2 & 2.3 \\
\cline { 2 - 4 } & $\mathrm{N}_{60} \mathrm{P}_{60} \mathrm{~K}_{60}$ & 148.7 & 2.2 \\
\cline { 2 - 4 } & $\mathrm{N}_{90} \mathrm{P}_{90} \mathrm{~K}_{90}$ & 142.3 & 2.2 \\
\cline { 2 - 4 } & $\mathrm{N}_{120} \mathrm{P}_{120} \mathrm{~K}_{120}$ & 157.2 & 2.3 \\
\hline
\end{tabular}

The total number of stems per 1 hectare increased with the increased density of planting. Thus, the density of planting of 42.8 thousand pcs./ha on the average resulted in the value of this indicator of 103 thousand pes/ha; 57.1-131.6 thousand pes/ha and 71.4-150.6 thousand pcs/ha. With the increase of planting density by 25 and $20 \%$, the number of the stems per 1 ha increased by 22 and 
$13 \%$, respectively. There is a proportional dependence of these indicators on each other, indicating by the paired correlation coefficient $(r=0.974 \pm 0.063)$. There is a strong correlation between the investigated factors and the indicator of the number of stems $(\mathrm{r}=0.975)$, a multiple determination coefficient $\left(\mathrm{r}^{2}=0.950\right)$ also indicates the dependence of a change in the density of stems on the effects of the studied factors.

The number of stems per 1 hectare at the same density of planting, but on different nutrition backgrounds, was almost identical. The differences were not significant, and consequently, the doses of fertilizers did not refer to the density of the stems. The pair correlation coefficient also indicates the lack of influence of the nutrition background on the density of stems $(r=0.073 \pm 0.277)$.

Height of the plants was determined at the flowering stage. The variant without fertilizer and at the maximum planting density (71.4 thousand pcs/ha) provided the lowest plants $-42 \mathrm{~cm}$. The highest this indicator was at the combination of the maximum thickening and nutrition background of $\mathrm{N}_{120} \mathrm{P}_{120} \mathrm{~K}_{120}-56 \mathrm{~cm}$. The results of the observations are marked in the Figure 1.

On the average for three years it is traced a clear dependence of the plants height on the fertilizers. So, on the average by the factor, in the variants without fertilizers the height of the plants was the lowest and reached $44 \mathrm{~cm}$, application of $\mathrm{N}_{30} \mathrm{P}_{30} \mathrm{~K}_{30}$ helped to increase the height by $4.2 \mathrm{~cm}$, with the dose of fertilizer $\mathrm{N}_{60} \mathrm{P}_{60} \mathrm{~K}_{60}$ the height was $50.5 \mathrm{~cm}$, and on the background of $\mathrm{N}_{90} \mathrm{P}_{90} \mathrm{~K}_{90}$ and $\mathrm{N}_{120} \mathrm{P}_{120} \mathrm{~K}_{120}$ the height of the plants was 54.7 and $55 \mathrm{~cm}$, respectively. The multiple correlation coefficient $(\mathrm{R}=0.951)$ indicates strong relation between the studied factors and the indicator of the plants height. The high degree of dependencies of the variations of the height of the plants on the investigated factors $(90.5 \%)$ is testified by the determination coefficient $\left(\mathrm{R}^{2}=0.905\right)$. The results of the correlation-based regression analysis of the research data point to the pretty high correlation relationship between the height of the plants and nutrition background, as it is evidenced by the calculated pair correlation coefficient $(\mathrm{r}=0.950 \pm 0.087)$. The plants height did not significantly depend on the increase in the density of planting $(\mathrm{r}=-0.033 \pm 0.277)$, by the scale of Cheddok - the correlation relationship is absent. 


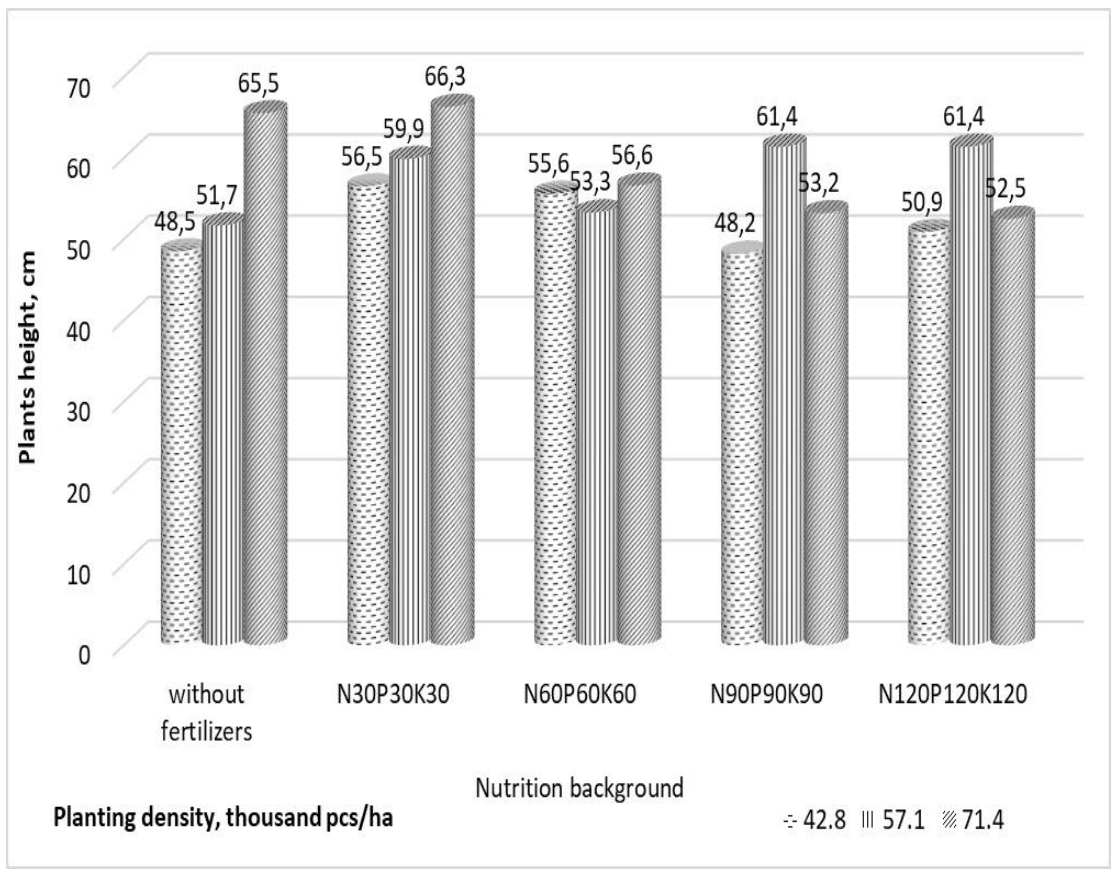

Fig. 1. The height of the potato plants of the spring planting at the flowering stage depending on the density of planting and nutrition background

Analysis of the crop evaluation showed that on the average for three years of the research, the smallest harvest was recorded on the variant with the lowest planting density (42.8 thousand pcs/ha) without fertilizers $-12.39 \mathrm{t} / \mathrm{ha}$. The largest economically justified harvest of tubers at the early harvesting was obtained by the applying of the planting density of 71.4 thousand pcs/ha and application of $60 \mathrm{~kg} / \mathrm{ha}$ of NPK $-21.42 \mathrm{t} / \mathrm{ha}$. Further enhancement of the dosage of fertilizer does not significantly increase the yield of tubers.

With the increasing density of planting tubers we observed the increased yield. If the density of planting increased by 25 and $40 \%$, the average difference in the yield of tubers between the variants with the lowest (42.8 thousand pcs/ha), and the highest (71.4 thousand pcs/ha) density of planting was $15.8 \%$ (Table 2). 


\section{Yield of potato tubers depending on the norms of fertilizers and planting density, $t / h a$}

\begin{tabular}{|c|c|c|c|c|}
\hline \multirow{3}{*}{$\begin{array}{l}\text { Nutrition background } \\
\text { (factor B) }\end{array}$} & \multicolumn{3}{|c|}{$\begin{array}{l}\text { The density of planting, } \\
\text { thousand pcs/ha (factor A) }\end{array}$} & \multirow{3}{*}{$\begin{array}{l}\text { The average by the } \\
\text { factor } \mathrm{B}, \\
\mathrm{LSD}_{05}=1.33 \mathrm{t} / \mathrm{ha}\end{array}$} \\
\hline & 42.8 & 57.1 & 71.4 & \\
\hline & \multicolumn{3}{|c|}{ Yield, t/ha } & \\
\hline Without fertilizers & 12.39 & 12.69 & 13.66 & 12.91 \\
\hline $\mathrm{N}_{30} \mathrm{P}_{30} \mathrm{~K}_{30}$ & 15.51 & 16.91 & 18.33 & 16.87 \\
\hline $\mathrm{N}_{60} \mathrm{P}_{60} \mathrm{~K}_{60}$ & 17.65 & 18.74 & 21.42 & 19.29 \\
\hline $\mathrm{N}_{90} \mathrm{P}_{90} \mathrm{~K}_{90}$ & 18.05 & 19.24 & 21.47 & 19.56 \\
\hline $\mathrm{N}_{120} \mathrm{P}_{120} \mathrm{~K}_{12}$ & 16.71 & 17.08 & 20.50 & 18.07 \\
\hline Average Factor A & 16.04 & 16.88 & 19.09 & \\
\hline
\end{tabular}

$\mathrm{LSD}_{05}$ for individual differences, t/ha: A 2.73

B 1.68

The dependence of the yields of tubers on the nutrition background is traced. According to the results of the studies, it is determined that the smallest crop regardless of the density of planting was on the control variant (without fertilizers) and was $12.91 \mathrm{t} / \mathrm{ha}$. Application of fertilizers at the dose of $60 \mathrm{~kg} / \mathrm{ha}$ of NPK, on the average by the factor, provided the maximum economically justified yield -19.29 t/ha. Further increased dosage of fertilizer does not significantly affect the productivity of early potato. Average difference with control (no fertilizer) and background fertilization of $\mathrm{N}_{90} \mathrm{P}_{90} \mathrm{~K}_{90}$ averaged to $34 \%$. Further increased dosage of fertilizer from 90 to $120 \mathrm{~kg} / \mathrm{ha}$ of NPK decreased the yield of tubers on average by 1.49 t/ha $(7.7 \%)$.

The results of the ANOVA indicate a strong relation between the yield index of potato variety Kobza and the investigated factors $(r=0.802)$. Determination coefficient $\left(R^{2}=0.644\right)$ indicates that the yield of potato depends on the impact of the studied factors by $64.4 \%$. Paired correlation coefficients confirm the previous assumption regarding the significant impact on the crop formation of the nutrition background $(r=0.667 \pm 0.207)$. The density of planting has moderate effect $(r=0.445 \pm 0.248)$ on the specified indicator.

The number of tubers under the bush was the largest at the least density of planting ( 42.8 thousand $\mathrm{pcs} / \mathrm{ha}$ ) and on the background of $\mathrm{N}_{90} \mathrm{P}_{90} \mathrm{~K}_{90}$ and averaged to $9.0 \mathrm{pcs} / \mathrm{bush}$, and the smallest number of 
them -4.5 pcs./bush was recorded on the variant without fertilizers and the most thickened background -71.4 thousand pcs./ha. The increasing density of planting resulted in fewer tubers under the bush. The number of tubers formed from thickening of the crops up to 57.1 thousand pcs/ha and 71.4 thousand pcs/ha decreased by 13 and $23.4 \%$, respectively (Table 3 ).

Fertilization allowed increasing the productivity of one plant. Thus, compared with the unfertilized variants for the density of planting of 42.8 thousand $\mathrm{pcs} / \mathrm{ha}$, the number of tubers under the bush increased by $15.6 \%$ at the application of $\mathrm{N}_{30} \mathrm{P}_{30} \mathrm{~K}_{30}$ up to $22.6 \%$ on the background of $\mathrm{N}_{90} \mathrm{P}_{90} \mathrm{~K}_{90}$, and for the density of planting of 57.1 thousand pcs/ha the number of tubers under the bush increased by $22.5 \%$ at the application of $\mathrm{N}_{30} \mathrm{P}_{30} \mathrm{~K}_{30}$ up to $26.6 \%$ on the background of $\mathrm{N}_{120} \mathrm{P}_{120} \mathrm{~K}_{120}$, and at the density of planting of 71.4 thousand $\mathrm{pcs} / \mathrm{ha}$, the difference between the variants without fertilizers and $\mathrm{N}_{30} \mathrm{P}_{30} \mathrm{~K}_{30}$ averaged to $22.4 \%$, and on the background of $\mathrm{N}_{120} \mathrm{P}_{120} \mathrm{~K}_{120}$ increased to $38.4 \%$.

Table 3

Indexes of the crop structure depending on the density of planting and fertilizer norms

\begin{tabular}{|c|c|c|c|}
\hline $\begin{array}{l}\text { The density } \\
\text { of planting, } \\
\text { thousand pcs/ha }\end{array}$ & $\begin{array}{c}\text { Nutrition } \\
\text { background }\end{array}$ & $\begin{array}{l}\text { Number of } \\
\text { tubers under the } \\
\text { bush, pcs/bush }\end{array}$ & $\begin{array}{c}\text { Weight } \\
\text { of average } \\
\text { tubers, } g\end{array}$ \\
\hline \multirow{5}{*}{42.8} & Without fertilizers & 6.5 & 48.8 \\
\hline & $\mathrm{N}_{30} \mathrm{P}_{30} \mathrm{~K}_{30}$ & 7.7 & 54.4 \\
\hline & $\mathrm{N}_{60} \mathrm{P}_{60} \mathrm{~K}_{60}$ & 8.5 & 55.3 \\
\hline & $\mathrm{N}_{90} \mathrm{P}_{90} \mathrm{~K}_{90}$ & 9.0 & 53.3 \\
\hline & $\mathrm{N}_{120} \mathrm{P}_{120} \mathrm{~K}_{120}$ & 8.4 & 47.8 \\
\hline \multirow{5}{*}{57.1} & Without fertilizers & 5.5 & 45.4 \\
\hline & $\mathrm{N}_{30} \mathrm{P}_{30} \mathrm{~K}_{30}$ & 7.1 & 45.7 \\
\hline & $\mathrm{N}_{60} \mathrm{P}_{60} \mathrm{~K}_{60}$ & 7.3 & 47.4 \\
\hline & $\mathrm{N}_{90} \mathrm{P}_{90} \mathrm{~K}_{90}$ & 7.4 & 46.8 \\
\hline & $\mathrm{N}_{120} \mathrm{P}_{120} \mathrm{~K}_{120}$ & 7.6 & 42.9 \\
\hline \multirow{5}{*}{71.4} & Without fertilizers & 4.5 & 43.1 \\
\hline & $\mathrm{N}_{30} \mathrm{P}_{30} \mathrm{~K}_{30}$ & 5.8 & 47.0 \\
\hline & $\mathrm{N}_{60} \mathrm{P}_{60} \mathrm{~K}_{60}$ & 6.3 & 47.6 \\
\hline & $\mathrm{N}_{90} \mathrm{P}_{90} \mathrm{~K}_{90}$ & 6.8 & 46.5 \\
\hline & $\mathrm{N}_{120} \mathrm{P}_{120} \mathrm{~K}_{120}$ & 7.3 & 42.6 \\
\hline
\end{tabular}


A multiple correlation coefficient indicates rather strong connection between the investigated factors and the formation of the total number of tubers under the bush: $R=0.935$. High dependence of the parameters of total quantity of tubers under the bush on the planting density was marked by the determination coefficient $\mathrm{R}^{2}=0.875$. Inverse-proportional pair correlation coefficient of the dependence of the total number of tubers under the bush on the planting density of potato $(r=-0.663 \pm 0.208)$ is an additional confirmation of the trend to the reduction of the number of tubers under the increasing density of their planting. Pair correlation coefficient $(\mathrm{r}=0,660 \pm 0.208)$ displays high directly proportional dependence of the studied indicator on the nutrition background of potato.

The difference in the indicator of the mass of tubers depended on the density of planting stronger. Average total mass of tubers was the highest at the smallest thickening of the planting (42.8 thousand $\mathrm{pcs} / \mathrm{ha}$ ) and averaged to $51.9 \mathrm{~g}$. By increasing the density of planting to 57.1 and 71.4 thousand $\mathrm{pcs} / \mathrm{ha}$, the mass of average tubers decreased by 14.3 and $13.9 \%$, respectively. The difference between the planting density of 57.1 and 71.4 thousand pcs/ha is considered insignificant.

On the background of nutrition $\mathrm{N}_{60} \mathrm{P}_{60} \mathrm{~K}_{60}$, the largest mass of average tubers was recorded on all the variants of planting density (42.8 thousand $\mathrm{pcs} / \mathrm{ha}-55.3 \mathrm{~g} ; 57.1-47.4$ and 71.4 thousand $\mathrm{pcs} / \mathrm{ha}-$ $47.6 \mathrm{~g})$.

According to the results of correlation-regression analysis, the connection between the mass indexes of tubers and the investigated factors is significant $(\mathrm{R}=0.568)$. Dependence of the variability of the mass of tubers, expressed by the determination coefficient, can be considered moderate $\left(\mathrm{R}^{2}=0.323\right)$. Inversely-proportional pair coefficient of correlation of the mass formation of the tubers from the density of the potato planting $(r=-0,703 \pm 0,097)$ is an additional proof of the tendency to the reduction of the mass of tubers depending on the increase in their density of planting. The pair correlation coefficient $(\mathrm{r}=-0,105 \pm 0.2,76)$ reflects the weak inversely-proportional dependence of the investigated indicator on the background of the potato nutrition.

The economic efficiency of local application of different doses of mineral fertilizers at different density of planting at an early harvest 
time was expected, based on the mass of the seed tubers of $50 \mathrm{~g}$, the price of planting material (Super-super-elite) - $4.78 \mathrm{UAH} / \mathrm{kg}$. The price of the sale was $8.5 \mathrm{UAH} / \mathrm{kg}$, respectively. The price of fertilizers was adopted as 10,100 UAH for 1 ton (Table 4).

Table 4

Economic efficiency of the densities of planting potato for different backgrounds of mineral nutrition at the spring planting and early harvesting

\begin{tabular}{|c|c|c|c|c|c|}
\hline 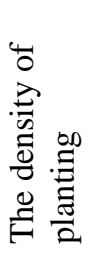 & 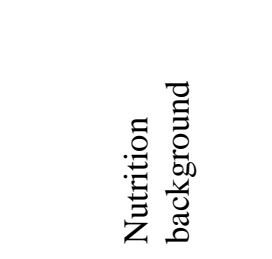 & 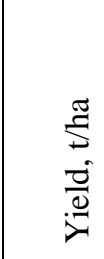 & 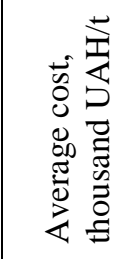 & 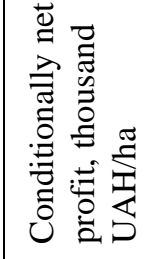 & 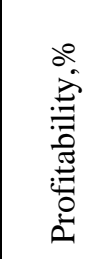 \\
\hline \multirow{5}{*}{42.8} & Without fertilizers & 12.39 & 4.19 & 47.16 & 91 \\
\hline & $\mathrm{N}_{30} \mathrm{P}_{30} \mathrm{~K}_{30}$ & 15.51 & 3.61 & 68.08 & 122 \\
\hline & $\mathrm{N}_{60} \mathrm{P}_{60} \mathrm{~K}_{60}$ & 17.65 & 3.37 & 81.69 & 137 \\
\hline & $\mathrm{N}_{90} \mathrm{P}_{90} \mathrm{~K}_{90}$ & 18.05 & 3.44 & 82.29 & 132 \\
\hline & $\mathrm{N}_{120} \mathrm{P}_{120} \mathrm{~K}_{120}$ & 16.71 & 3.82 & 69.90 & 110 \\
\hline \multirow{5}{*}{57.1} & Without fertilizers & 12.69 & 4.58 & 43.37 & 75 \\
\hline & $\mathrm{N}_{30} \mathrm{P}_{30} \mathrm{~K}_{30}$ & 16.91 & 3.71 & 72.52 & 116 \\
\hline & $\mathrm{N}_{60} \mathrm{P}_{60} \mathrm{~K}_{60}$ & 18.74 & 3.53 & 83.80 & 127 \\
\hline & $\mathrm{N}_{90} \mathrm{P}_{90} \mathrm{~K}_{90}$ & 19.24 & 3.57 & 85.16 & 124 \\
\hline & $\mathrm{N}_{120} \mathrm{P}_{120} \mathrm{~K}_{120}$ & 17.08 & 4.10 & 66.63 & 95 \\
\hline \multirow{5}{*}{71.4} & Without fertilizers & 13.66 & 4.74 & 44.59 & 69 \\
\hline & $\mathrm{N}_{30} \mathrm{P}_{30} \mathrm{~K}_{30}$ & 18.33 & 3.54 & 70.67 & 93 \\
\hline & $\mathrm{N}_{60} \mathrm{P}_{60} \mathrm{~K}_{60}$ & 21.42 & 3.43 & 97.80 & 133 \\
\hline & $\mathrm{N}_{90} \mathrm{P}_{90} \mathrm{~K}_{90}$ & 21.47 & 3.54 & 95.79 & 126 \\
\hline & $\mathrm{N}_{120} \mathrm{P}_{120} \mathrm{~K}_{12}$ & 20.50 & 3.80 & 86.16 & 111 \\
\hline
\end{tabular}

Analysis of the economic efficiency indexes for different density of planting and local application of different doses of fertilizers under the potato early harvesting showed that the seed material production on all the variants was profitable. However, the additional cost of seed material reduced profitability on the variants without fertilizer. So, with an increase in the density of planting to 
57.1 thousand tubers/ha without the use of fertilizers we received the least conditional net profit of $43,370 \mathrm{UAH} / \mathrm{ha}$, and the increase in the density to 71.4 thousand/ha $(20 \%)$ did not provide significant increase in the profits, which amounted to $44,590 \mathrm{UAH} / \mathrm{ha}$, or increased by $2.7 \%$. The use of fertilizers in the dose of $30 \mathrm{~kg} / \mathrm{ha}$ NPK increases the cost of production by 6,640 UAH/ha, at the same time, the price of additional products was $24,960 \mathrm{UAH}$, and the net profit of 20,920 UAH/ha.

The level of the net profit in the production of seed material of higher reproductions is the best result obtained in the application of the density of planting 71.4 thousand tubers/ha and fertilizer application rates of $60 \mathrm{~kg} / \mathrm{ha} \mathrm{NPK}-97,800 \mathrm{UAH} / \mathrm{ha}$.

That is, according to the results of the three years of the research, to receive seed material of higher reproductions of the variety Kobza at the spring planting and early harvesting and local application of nitroammofoska, the dosage of fertilizers should be appointed at the rate of $60 \mathrm{~kg} / \mathrm{ha}$ of NPK, and the density of planting -71.4 thousand tubers/ha.

\section{Influence of the nutrition level and density of planting on the productivity of seed potatoes at the summer planting with fresh-harvested tubers}

In the South of Ukraine, the best way to obtain a potato seed material, which is to a lesser extent exposed to the degeneration under the influence of high air temperatures, is summer planting of freshly harvested tubers in the double-crop. This method is used in the scientific and research institutions for the reproduction of the elite in the Steppe zone. After all, at the time of tubers formation in the second crop, during the vegetation period the temperature regime of environment decreases that is favorable for the conservation of the productive qualities of seed material ${ }^{10}$.

In 2007-2008 at the Institute of irrigated Agriculture of NAAS the experiment was carried out, which envisaged the determination of the

${ }^{10}$ Potato: Variety change and renewal / O. Vyshnevska // Propozytsiya. 2017. No. 1. P. 126-128. 
impact on the performance of the summer planting potato by using different norms of complex mineral fertilizers and the density of planting of fresh tubers of the variety of potato Kobza. Planting material was treated by 4-component solution of stimulants to interrupt the period of rest and planted in the field according to the scheme of the experiment in late June.

Field germination in the experiment was quite high - from 73.1 to $100 \%$. Average indicators of field germination on the background of different density of planting had differences. Thus, on the background of the planting density of 42.8 thousand pcs/ha, the average value of this indicator was the lowest and reached $86.7 \%$. The maximum average indicator was fixed with an increase of thickening to 57.1 thousand $\mathrm{pcs} / \mathrm{ha}-97.4 \%$. At the highest level of planting density (71.4 thousand pcs/ha) field germination averaged to $92.2 \%$ (Table 5).

Field germination was the minimum at the application of the highest dose of fertilizers $\left(\mathrm{N}_{120} \mathrm{P}_{120} \mathrm{~K}_{120}\right)$, on the average, $82.1 \%$. On the other backgrounds, this index did not have significant differences and reached $95 \%$. On the variant without fertilizers there were $92.7 \%$ of the germinated plants.

According to the results of correlation-regression analysis, this index almost did not depend on the studied factors $(\mathrm{R}=0.474$; $R^{2}=0.225$ ). Pair correlation coefficients also indicate a faint effect of factors on the field germination of the plants: the density of planting $(\mathrm{r}=0.287 \pm 0.266)$ and moderate - nutrition background $(\mathrm{r}=-0.378 \pm 0.277)$.

The minimum index of the plant height in the experiment $(48.2 \mathrm{~cm})$ was recorded on the variant with the nutrition background $\mathrm{N}_{90} \mathrm{P}_{90} \mathrm{~K}_{90}$ at the density of planting 42.8 thousand pcs/ha, the maximum $(66.3 \mathrm{~cm})$ - at the application of $\mathrm{N}_{30} \mathrm{P}_{30} \mathrm{~K}_{30}$ and the density of planting 71.4 thousand pcs/ha. The height of the plant at the planting density of 42.8 thousand $\mathrm{pcs} / \mathrm{ha}$ was the smallest and averaged to $51.9 \mathrm{~cm}$. At the density of planting of 57.1 thousand tubers $/ \mathrm{ha}$, the average value of this indicator was at the level of $57.5 \mathrm{~cm}$. At thickening of the planting up to 71.4 thousand pcs/ha, the average index of the height of the plants was $58.8 \mathrm{~cm}$ (Fig. 2). 
Table 5

\section{Development of the plants of potato of early-ripening variety Kobza at the summer planting at different planting density and norms of fertilization}

\begin{tabular}{|c|l|c|c|}
\hline \multirow{2}{*}{$\begin{array}{c}\text { The density } \\
\text { of planting }\end{array}$} & \multicolumn{1}{|c|}{$\begin{array}{c}\text { Nutrition } \\
\text { background }\end{array}$} & $\begin{array}{c}\text { Field } \\
\text { germination, } \%\end{array}$ & $\begin{array}{c}\text { Number of stems } \\
\text { per bush, pcs. }\end{array}$ \\
\hline \multirow{5}{*}{42.8} & $\begin{array}{l}\text { Without } \\
\text { fertilizers }\end{array}$ & 87.0 & 2.9 \\
\cline { 2 - 4 } & $\mathrm{N}_{30} \mathrm{P}_{30} \mathrm{~K}_{30}$ & 91.7 & 3.4 \\
\cline { 2 - 4 } & $\mathrm{N}_{60} \mathrm{P}_{60} \mathrm{~K}_{60}$ & 91.7 & 3.1 \\
\cline { 2 - 4 } & $\mathrm{N}_{90} \mathrm{P}_{90} \mathrm{~K}_{90}$ & 89.8 & 2.8 \\
\cline { 2 - 4 } & $\mathrm{N}_{120} \mathrm{P}_{120} \mathrm{~K}_{120}$ & 73.1 & 2.6 \\
\hline \multirow{5}{*}{57.1} & $\mathrm{Without}_{7}$ & 91.0 & 3.5 \\
\cline { 2 - 4 } & fertilizers & 99.3 & 3.1 \\
\cline { 2 - 4 } & $\mathrm{N}_{30} \mathrm{P}_{30} \mathrm{~K}_{30}$ & 100 & 3.2 \\
\cline { 2 - 4 } & $\mathrm{N}_{60} \mathrm{P}_{60} \mathrm{~K}_{60}$ & 100 & 3.5 \\
\cline { 2 - 4 } & $\mathrm{N}_{90} \mathrm{P}_{90} \mathrm{~K}_{90}$ & 96.5 & 4.4 \\
\cline { 2 - 4 } & $\mathrm{N}_{120} \mathrm{P}_{120} \mathrm{~K}_{120}$ & 100 & 2.4 \\
\hline \multirow{5}{*}{71.4} & $\mathrm{Without}_{1}$ & 94.0 & 4.1 \\
\cline { 2 - 4 } & fertilizers & 94.0 & 2.3 \\
\cline { 2 - 4 } & $\mathrm{N}_{30} \mathrm{P}_{30} \mathrm{~K}_{30}$ & 96.2 & 2.7 \\
\cline { 2 - 4 } & $\mathrm{N}_{60} \mathrm{P}_{60} \mathrm{~K}_{60}$ & 76.6 & 1.6 \\
\cline { 2 - 4 } & $\mathrm{N}_{90} \mathrm{P}_{90} \mathrm{~K}_{90}$ & & \\
\cline { 2 - 4 } & $\mathrm{N}_{120} \mathrm{P}_{120} \mathrm{~K}_{120}$ & & \\
\hline
\end{tabular}

By the nutrition background there were no sharp fluctuations in the height of the plants. The highest were plants at the application of $\mathrm{N}_{30} \mathrm{P}_{30} \mathrm{~K}_{30}$ - the average by the variant value was $60.9 \mathrm{~cm}$. In the variant with application of fertilizers $\mathrm{N}_{90} \mathrm{P}_{90} \mathrm{~K}_{90}$, the minimum indicators of the plant height $-54.3 \mathrm{~cm}$ were noted. On the remaining variants (without fertilizers, $\mathrm{N}_{60} \mathrm{P}_{60} \mathrm{~K}_{60}, \mathrm{~N}_{120} \mathrm{P}_{120} \mathrm{~K}_{120}$ ), there were no significant differences in this index, the height of the plant was within the range of $55 \mathrm{~cm}$.

According to the results of correlation-regression analysis, the average closeness of connection $(R=0.540)$ is revealed between the studied factors and the indicator of plant height. Dependence of the plants height on the influence of the planting density of tubers and the nutrition background can be considered weak, but close to moderate 
$\left(R^{2}=0.292\right)$. Pair correlation coefficients indicate a noticeable effect of the density $(\mathrm{r}=0.507 \pm 0.239)$ by the Cheddok scale, and the weak $(\mathrm{r}=-0.189 \pm 0.273)$ - for the nutrition background.

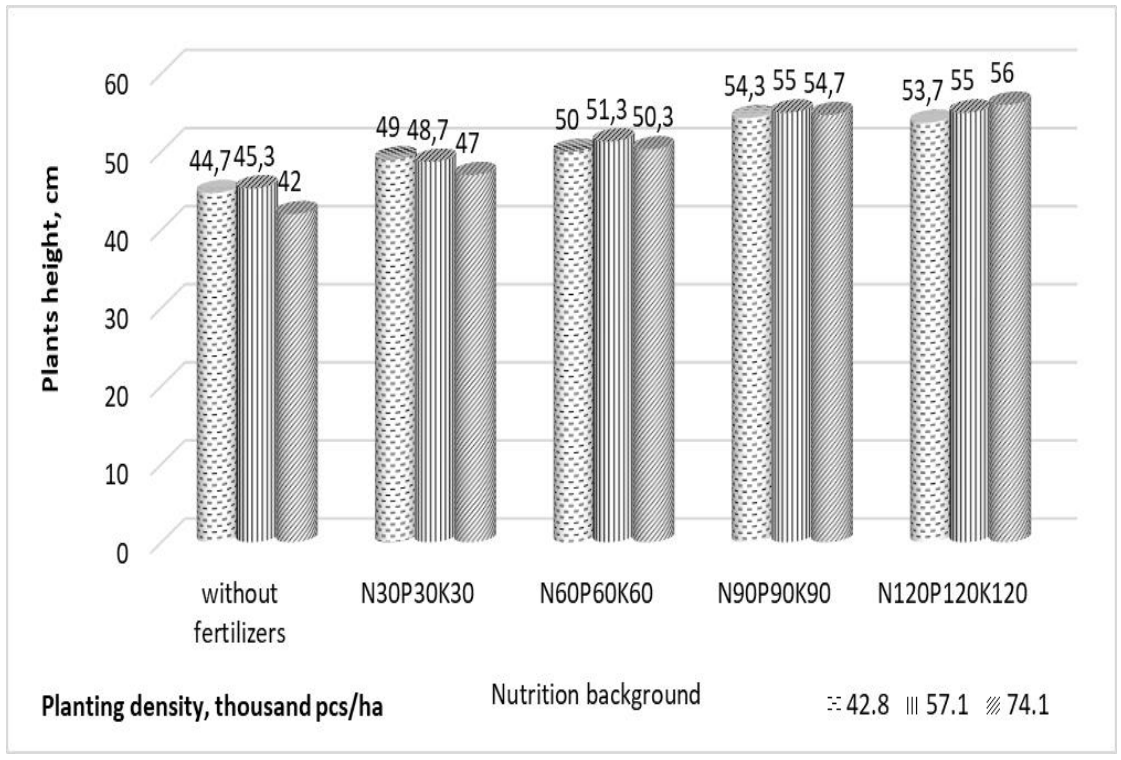

Fig. 2. Summer planting potato plants height at the flowering stage depending on the density of planting and nutrition background

An evident tendency of the influence of the studied factors on the formation of the number of stems per bush was not found. The maximum number of them on the experiment ( $4.4 \mathrm{pcs} / \mathrm{bush})$ was determined by the version with the density of planting of 57.1 thousand $\mathrm{pcs} / \mathrm{ha}$, the minimum - at the thickening of 71.4 thousand pcs/ha and at the same power background $-\mathrm{N}_{120} \mathrm{P}_{120} \mathrm{~K}_{120}$.

The case in the development of the plants in the experiment was not found - the stage of budding and flowering took place in all the variants of the experiment.

The evaluation of crop showed that the conditions of years of the research were quite different. Rough weather conditions for the formation of the crop of tubers differed in 2007, where the density of planting of 42.8 thousand pcs/ha provided the average yield index of $10.41 \mathrm{t} / \mathrm{ha}$, at thickening to 57.1 thousand -10.92 and at the 71.4 
thousand $\mathrm{pcs} / \mathrm{ha}-12.3 \mathrm{t} / \mathrm{ha}$, which is less than $40.9 ; 41.3$ and $47.5 \%$, respectively, in comparison to 2008 , the more drastic fluctuations in the yield indexes were observed as a result of the application of different nutrition backgrounds. Thus, the average yield on the control variant (without fertilizers) was $8.61 \mathrm{t} / \mathrm{ha}$, at the application of $30 \mathrm{~kg} / \mathrm{ha}$ NPK $-10.8 \mathrm{t} / \mathrm{ha}$, at $60 \mathrm{~kg} / \mathrm{ha}$ NPK -11.5 and on the background of 90 and $120 \mathrm{~kg} / \mathrm{ha}$ NPK - $12.57 \mathrm{t} / \mathrm{ha}$, which was less than in 2008 to 39.1; 40.6; 42.0 and 45.2 and $48.9 \%$, respectively (Table 6).

Table 6

\section{The yield of potato tubers of the variety Kobza depending on the norms of fertilizers and planting density in the summer planting, $\mathrm{t} / \mathrm{ha}$}

\begin{tabular}{|c|c|c|c|c|}
\hline $\begin{array}{l}\text { The density of planting, } \\
\text { thousand pcs/ha }\end{array}$ & $\begin{array}{c}\text { Nutrition } \\
\text { background }\end{array}$ & 2007 & 2008 & Average \\
\hline \multirow{5}{*}{42.8} & Without fertilizers & 8.53 & 21.31 & 14.92 \\
\hline & $\mathrm{N}_{30} \mathrm{P}_{30} \mathrm{~K}_{30}$ & 9.81 & 26.61 & 18.21 \\
\hline & $\mathrm{N}_{60} \mathrm{P}_{60} \mathrm{~K}_{60}$ & 10.40 & 27.83 & 19.12 \\
\hline & $\mathrm{N}_{90} \mathrm{P}_{90} \mathrm{~K}_{90}$ & 11.50 & 28.47 & 19.99 \\
\hline & $\mathrm{N}_{120} \mathrm{P}_{120} \mathrm{~K}_{120}$ & 11.80 & 22.93 & 17.37 \\
\hline \multirow{5}{*}{57.1} & Without fertilizers & 8.70 & 21.96 & 15.33 \\
\hline & $\mathrm{N}_{30} \mathrm{P}_{30} \mathrm{~K}_{30}$ & 10.20 & 26.53 & 18.37 \\
\hline & $\mathrm{N}_{60} \mathrm{P}_{60} \mathrm{~K}_{60}$ & 10.60 & 27.77 & 19.19 \\
\hline & $\mathrm{N}_{90} \mathrm{P}_{90} \mathrm{~K}_{90}$ & 12.40 & 28.17 & 20.29 \\
\hline & $\mathrm{N}_{120} \mathrm{P}_{120} \mathrm{~K}_{120}$ & 12.70 & 27.69 & 20.20 \\
\hline \multirow{5}{*}{71.4} & Without fertilizers & 8.60 & 22.85 & 15.73 \\
\hline & $\mathrm{N}_{30} \mathrm{P}_{30} \mathrm{~K}_{30}$ & 12.40 & 26.74 & 19.57 \\
\hline & $\mathrm{N}_{60} \mathrm{P}_{60} \mathrm{~K}_{60}$ & 13.50 & 26.53 & 20.02 \\
\hline & $\mathrm{N}_{90} \mathrm{P}_{90} \mathrm{~K}_{90}$ & 13.80 & 26.85 & 20.33 \\
\hline & $\mathrm{N}_{120} \mathrm{P}_{120} \mathrm{~K}_{120}$ & 13.20 & 26.50 & 19.85 \\
\hline & $\mathrm{LSD}_{05} \mathrm{I}$ & 1.51 & 1.62 & \\
\hline & $\mathrm{LSD}_{05} \mathrm{II}$ & 1.16 & 1.25 & \\
\hline & $\mathrm{LSD}_{05} \mathrm{~A}$ & 0.68 & 0.901 & \\
\hline & $\mathrm{LSD}_{05} \mathrm{~B}$ & 0.67 & 1.02 & \\
\hline
\end{tabular}


The investigated factors had influence on the formation of the crop in 2007, this is indicated by the results of the correlationregression analysis of the data. A multiple correlation coefficient $(\mathrm{R}=0.900)$ confirms strong connection between the investigated factors and the formation of the yield of tubers. Determination coefficient $\left(R^{2}=0.811\right)$ characterizes the high dependence of the yield indicators on the planting density and nutrition background. Pair correlation coefficient revealed the moderate impact of the density of planting $(r=0.443 \pm 0.249)$ and strong effect of nutrition background $(\mathrm{r}=0.784 \pm 0.172)$ on the studied indicators.

In 2008 the weather conditions contributed to the accumulation of great levels of the tubers yields. By the factor of the density of planting there were no steep fluctuations observed. The most comfortable conditions for the formation of the yield were formed on the background of plants thickening to 57.1thousand pcs/ha, with the average value of $26.42 \mathrm{t} / \mathrm{ha}$. The increase in the dose of fertilizers up to 30,60 and $90 \mathrm{~kg} / \mathrm{ha}$ of NPK contributed to an increase in yield by an average of $4.59 \mathrm{t} / \mathrm{ha}, 5.34$ and $5.79 \mathrm{t} / \mathrm{ha}$ or $17.2 \%, 19.5$ and $20.8 \%$, respectively, compared with the unfertilized variant. Further increase in the dosage of fertilizer from 90 up to $120 \mathrm{~kg} / \mathrm{ha}$ of NPK led to a decrease in the yield of tubers by $2.12 \mathrm{t} / \mathrm{ha}$, or $7.6 \%$.

According to the results of correlation-regression analysis of the data, the factors had a noticeable impact by the scale of the Cheddok on the formation of the yield in 2008, this is specified by the multiple correlation coefficient $(\mathrm{R}=0.529)$. Weak variability of the yield indicators from the influence of the planting density and nutrition background is characterized by the determination coefficient $\left(\mathrm{r}^{2}=0.279\right)$. The pair correlation coefficient $(\mathrm{r}=0.082 \pm 0.276)$ indicates the lack of the effects of planting density and the noticeable impact of nutrition background $(\mathrm{r}=0.522 \pm 0.237)$ on the formation of a potato variety Kobza yield at the summer planting of 2008 .

An important structural characteristic of the crop is the number of tubers formed under one bush. By the research results the dependence of this index on the investigated factors was found out. So, with the increasing density of planting the number of tubers decreased: from $5.3 \mathrm{pcs} / \mathrm{bush}$ - on the background with the smallest thickness (42.8 thousand pcs/ha) to $4.8 \mathrm{pcs} / \mathrm{bush}$ - at the largest density of planting (71.4 thousand pcs/ha), or by $9.4 \%$. The pair 
correlation coefficient is inverse $(r=-0.448 \pm 0.248)$ and points to a moderate, but stronger, influence of the planting density factor on the formation of the number of tubers per bush. By the increasing dosage of fertilizers to $90 \mathrm{~kg} / \mathrm{ha}$ of NPK the tendency to the formation of more tubers per bush from 4.8 PCs. to $5.2 \mathrm{pcs} / \mathrm{bush}$, or $7.7 \%$, was observed. Further increase in the nutrition background from 90 to $120 \mathrm{~kg} / \mathrm{ha}$ of NPK resulted in no changes in the number of tubers. The correlation coefficient between the nutrition background and the indicated value is moderate $(r=0.300 \pm 0.265)$, but slightly less than of the density of planting. The multiple correlation coefficient $(r=0.539)$ indicates significant closeness in the relationship between the investigated factors and the formation of the tubers per one bush. The determination coefficient $\left(\mathrm{R}^{2}=0.290\right)$ is an indicator of the fact that the impact of the investigated factors on the amount of tubers was $29 \%$ (Table 7).

Table 7

Structure of the crop of potato variety Kobza in the summer planting depending on the norms of fertilizers and density of planting

\begin{tabular}{|c|c|c|c|}
\hline $\begin{array}{c}\text { The density } \\
\text { of planting, } \\
\text { thousand pcs/ha }\end{array}$ & $\begin{array}{l}\text { Nutrition } \\
\text { background }\end{array}$ & $\begin{array}{l}\text { Number of } \\
\text { tubers under } \\
\text { the bush, pcs }\end{array}$ & $\begin{array}{l}\text { Weight of } \\
\text { average } \\
\text { tubers, } g\end{array}$ \\
\hline \multirow{5}{*}{42.8} & Without fertilizers & 5.1 & 94.5 \\
\hline & $\mathrm{N}_{30} \mathrm{P}_{30} \mathrm{~K}_{30}$ & 4.4 & 114.2 \\
\hline & $\mathrm{N}_{60} \mathrm{P}_{60} \mathrm{~K}_{60}$ & 5.2 & 107.2 \\
\hline & $\mathrm{N}_{90} \mathrm{P}_{90} \mathrm{~K}_{90}$ & 6.1 & 93.5 \\
\hline & $\mathrm{N}_{120} \mathrm{P}_{120} \mathrm{~K}_{120}$ & 5.7 & 98.1 \\
\hline \multirow{5}{*}{57.1} & Without fertilizers & 4.7 & 93.0 \\
\hline & $\mathrm{N}_{30} \mathrm{P}_{30} \mathrm{~K}_{30}$ & 5.3 & 81.3 \\
\hline & $\mathrm{N}_{60} \mathrm{P}_{60} \mathrm{~K}_{60}$ & 4.7 & 93.4 \\
\hline & $\mathrm{N}_{90} \mathrm{P}_{90} \mathrm{~K}_{90}$ & 4.8 & 90.0 \\
\hline & $\mathrm{N}_{120} \mathrm{P}_{120} \mathrm{~K}_{120}$ & 5.0 & 95.6 \\
\hline \multirow{5}{*}{71.4} & Without fertilizers & 4.5 & 81.0 \\
\hline & $\mathrm{N}_{30} \mathrm{P}_{30} \mathrm{~K}_{30}$ & 5.4 & 87.9 \\
\hline & $\mathrm{N}_{60} \mathrm{P}_{60} \mathrm{~K}_{60}$ & 4.6 & 86.2 \\
\hline & $\mathrm{N}_{90} \mathrm{P}_{90} \mathrm{~K}_{90}$ & 4.7 & 99.7 \\
\hline & $\mathrm{N}_{120} \mathrm{P}_{120} \mathrm{~K}_{120}$ & 4.8 & 103.3 \\
\hline
\end{tabular}


The mass of average tubers changed under the influence of the studied factors. With the increase of planting density, weight of tubers was reduced by the average of $9.8 \%$ - from $101.5 \mathrm{~g}$ at the least thickened variant (42.8 thousand pcs./ha) to $91.6 \mathrm{~g}-$ at the most thick crops (71.4 thousand pcs./ha). The pair correlation coefficient $(r=-0.458 \pm 0.247)$ indicates the correctness of our assumption. The increase of the doses of fertilizers positively influenced the formation of the tubers weight. On the unfertilized background, the minimum value of this indicator was fixed $89.5 \mathrm{~g}$, and the maximum mass of the average tubers was observed on the background of $120 \mathrm{~kg} / \mathrm{ha}$ of NPK and was $99.0 \mathrm{~g}$ - the difference between the indexes was $9.6 \%$. Weight dependence degree of the tubers weight on the nutrition background is moderate, according to the pair correlation coefficient $(\mathrm{r}=0.304 \pm 0.264)$. The multiple correlation coefficient $(\mathrm{R}=0.550)$ indicates significant closeness of the relationship between the investigated factors and the mass of the avergae tubers. The simultaneous influence of the factors of the planting of tubers and the nutrition background on the mass indicator of the average tuber is characterized as insignificant $\left(\mathrm{R}^{2}=0.303\right)$.

The indexes of the economic efficiency of the use of local fertilizer for potato of the summer planting show that at growing seed material all the studied options were profitable.

The economic efficiency of cultivation of the summer planted potato at different nutrition backgrounds and the density of planting was evaluated on the basis of the mass of the planting tubers, the price of planting material of $50 \mathrm{~g}$ (super-super-elite) - 8500UAH/t. The sale price is $10 \mathrm{UAH} / \mathrm{kg}$. The price of the fertilizer was $10,100 \mathrm{UAH} / \mathrm{ton}$ (Table 8).

The least production cost was obtained at the density of planting of 42.8 thousand pcs/ha and nutrition background of $\mathrm{N}_{90} \mathrm{P}_{90} \mathrm{~K}_{90}-$ 3.62 thousand $\mathrm{UAH} / \mathrm{t}$, as a consequence, the specified variant was the most profitable (127.49 thousand/ha) and the most cost-effective $176 \%$. The opposite values of the indexes were fixed on the variant without fertilizers and with the density of planting of 71.4 thousand $\mathrm{pcs} / \mathrm{ha}-4.41$ thousand $\mathrm{UAH} / \mathrm{t}, 88.01$ thousand $\mathrm{UAH} / \mathrm{ha}$ and $127 \%$, respectively. 
Table 8

Economic efficiency of the application of the density of planting potato at different backgrounds of mineral nutrition of potato at the summer with freshly harvested tubers

\begin{tabular}{|c|c|c|c|c|c|}
\hline $\begin{array}{l}\text { The } \\
\text { density } \\
\text { of the } \\
\text { planting }\end{array}$ & $\begin{array}{c}\text { Nutrition } \\
\text { background }\end{array}$ & $\begin{array}{c}\text { Yield, } \\
\text { t/ha }\end{array}$ & $\begin{array}{c}\text { Average } \\
\text { cost, } \\
\text { thousand } \\
\text { UAH/t }\end{array}$ & $\begin{array}{c}\text { Conditionally } \\
\text { net profit, } \\
\text { thousand } \\
\text { UAH/ha }\end{array}$ & $\begin{array}{c}\text { Profitability, } \\
\%\end{array}$ \\
\hline \multirow{5}{*}{42.8} & $\begin{array}{l}\text { Without } \\
\text { fertilizers }\end{array}$ & 14.92 & 4.03 & 89.12 & 148 \\
\hline & $\mathrm{N}_{30} \mathrm{P}_{30} \mathrm{~K}_{30}$ & 18.21 & 3.69 & 113.98 & 167 \\
\hline & $\mathrm{N}_{60} \mathrm{P}_{60} \mathrm{~K}_{60}$ & 19.12 & 3.70 & 120.40 & 170 \\
\hline & $\mathrm{N}_{90} \mathrm{P}_{90} \mathrm{~K}_{90}$ & 19.99 & 3.62 & 127.49 & 176 \\
\hline & $\mathrm{N}_{120} \mathrm{P}_{120} \mathrm{~K}_{120}$ & 17.37 & 4.21 & 100.61 & 138 \\
\hline \multirow{5}{*}{57.1} & $\begin{array}{l}\text { Without } \\
\text { fertilizers }\end{array}$ & 15.33 & 4.22 & 88.61 & 137 \\
\hline & $\mathrm{N}_{30} \mathrm{P}_{30} \mathrm{~K}_{30}$ & 18.37 & 3.89 & 111.12 & 153 \\
\hline & $\mathrm{N}_{60} \mathrm{P}_{60} \mathrm{~K}_{60}$ & 19.19 & 3.90 & 115.98 & 153 \\
\hline & $\mathrm{N}_{90} \mathrm{P}_{90} \mathrm{~K}_{90}$ & 20.29 & 3.89 & 124.03 & 157 \\
\hline & $\mathrm{N}_{120} \mathrm{P}_{120} \mathrm{~K}_{120}$ & 20.20 & 4.02 & 120.88 & 149 \\
\hline \multirow{5}{*}{71.4} & $\begin{array}{l}\text { Without } \\
\text { fertilizers }\end{array}$ & 15.73 & 4.41 & 88.01 & 127 \\
\hline & $\mathrm{N}_{30} \mathrm{P}_{30} \mathrm{~K}_{30}$ & 19.57 & 4.04 & 116.59 & 147 \\
\hline & $\mathrm{N}_{60} \mathrm{P}_{60} \mathrm{~K}_{60}$ & 20.02 & 4.03 & 119.47 & 148 \\
\hline & $\mathrm{N}_{90} \mathrm{P}_{90} \mathrm{~K}_{90}$ & 20.33 & 4.00 & 121.95 & 150 \\
\hline & $\mathrm{N}_{120} \mathrm{P}_{120} \mathrm{~K}_{120}$ & 19.85 & 4.27 & 113.85 & 134 \\
\hline
\end{tabular}

The highest yield of tubers was obtained by applying the density of planting potato variety Kobza in the summer terms at 57.1 and 71.4 thousand pcs/ha and applying $90 \mathrm{~kg} / \mathrm{ha}$ of NPK - respectively, 20.29 and $20.33 \mathrm{t} / \mathrm{ha}$. In the same group by the performance with these variants there were the density of 42.8 thousand pcs./ha $+90 \mathrm{~kg} / \mathrm{ha}$ of NPK, 71.4 thousand pcs/ha $+60 \mathrm{~kg} / \mathrm{ha}$ of NPK. That is, if we have to choose the least expensive variant, it is the best variant to plant with the density of 42.8 thousand pcs/ha $+90 \mathrm{~kg} / \mathrm{ha}$ of NPK. 


\section{CONCLUSIONS}

1. The maximum performance and out pay of the investment at the determination of the optimum elements of cultivation technology of potato seed material of higher categories at the spring planting and early harvesting is obtained under the application of the density of planting of 71.4 thousand pcs/ha and local mineral fertilizer application in the dose of $\mathrm{N}_{60} \mathrm{P}_{60} \mathrm{~K}_{60}$. The yield in this case is $21.42 \mathrm{t} / \mathrm{ha}$, conditionally net profit $-97,800 \mathrm{UAH} / \mathrm{ha}$, production cost of the unit 3.43 thousand $\mathrm{UAH} / \mathrm{t}$, profitability $-133 \%$.

2. At the obtaining seed potatoes at the summer planting with freshly collected tubers, the largest yield of tubers was at the application of the density of planting potato variety Kobza in the summer terms of 57.1 and 71.4 thousand pcs/ha and application of $\mathrm{N}_{90} \mathrm{P}_{90} \mathrm{~K}_{90}$ - respectively, 20.29 and $20.33 \mathrm{t} / \mathrm{ha}$. But the most economically feasible is the combination of the main elements of cultivation: planting density of 42.8 thousand $\mathrm{pcs} / \mathrm{ha}$ and local application of fertilizer in the dose of $\mathrm{N}_{90} \mathrm{P}_{90} \mathrm{~K}_{90}$. The yield in this case was $19.99 \mathrm{t} / \mathrm{ha}$, conditionally net profit - 115,980 UAH/ha, the production cost of the unit -3.62 thousand $\mathrm{UAH} / \mathrm{t}$, profitability $176 \%$.

3. The studied factors had different impact on the formation of the crop over the years. Multiple correlation coefficients under the conditions of the spring $(\mathrm{R}=0.802)$ and summer planting $(\mathrm{r}=0.900)$ and coefficient of determination $\left(r^{2}=0.811\right)$ and $\left(R^{2}=0.644\right)$ confirm strong connection between the investigated factors and the formation of the yield of tubers in the unfavorable weather-climatic conditions of 2007. In 2008, the dependence indicators in the conditions of the spring $(R=0.529)$ and summer planting $\left(R^{2}=0.279\right)$ indicate a reduction in the impact of the studied factors and positive impact of the environmental conditions on the improvement of the seed productivity. Nutritive supply, both in the conditions of spring $(r=0.667 \pm 0.207)$ and summer planting $(\mathrm{r}=0.784 \pm 0.172)$ had more significant impact on the yield value than the density of planting $(r=0.443 \pm 0.249)$ and $(\mathrm{r}=0.445 \pm 0.248)$, respectively.

\section{SUMMARY}

The paper considers the question of the determination of the optimal norms of mineral fertilizers application by the local method at 
the different density of planting for the conditions of spring and summer planting. As a result of the research on the cultivation of higher categories of potato seed material at the spring planting and early harvesting it is recommended to apply the density of planting of 71.4 thousand tubers at the local application of mineral fertilizers in the dose of $\mathrm{N}_{60} \mathrm{P}_{60} \mathrm{~K}_{60}$. The yield in this case is $21.42 \mathrm{t} / \mathrm{ha}$, conditionally net profit - 97,800 UAH/ha, the production cost of the unit is 3.43 thousand $\mathrm{UAH} / \mathrm{t}$, profitability - 133\%. Regarding the determination of the cultivation productivity of seed potato at the summer planting with freshly collected tubers it should be noted that the most cost-effective combination of the main elements of cultivation was: planting density of 42.8 thousand pes/ha at the local application of mineral fertilizers in the dose of $\mathrm{N}_{90} \mathrm{P}_{90} \mathrm{~K}_{90}$. The yield in this case is $19.99 \mathrm{t} / \mathrm{ha}$, the conditionally net profit - 115,980 UAH/ha, the production cost of the unit -3.62 thousand $\mathrm{UAH} / \mathrm{t}$, profitability $176 \%$. The effect of nutrition background on most productivity indicators, according to the results of the correlation-regression analysis, proved to be more significant than of the density of planting.

\section{REFERENCES}

1. Базалій В.В., Зінченко О.І., Лавриненко Ю.О., Салатенко В.Н., Коковіхін С.В., Домарацький Є.О. Рослинництво : Підручник; за ред. В.В. Базалія, О.І. Зінченка, Ю.О. Лавриненка. Херсон : Грінь Д.С., 2014. 461 с.: іл.

2. Бондарчук А.А. Наукові основи насінництва картоплі в Україні : монографія. Біла Церква, 2010. 400 с.

3. Вильдфлуш И. Р. Локальное внесение удобрений - одно из главных средств рационального и экономного использования минеральных удобрений. Агрохимия. 1996. Вып. 10. С. 132-141.

4. Власенко М. Ю., Руденко Г. С. Вплив різних норм мінеральних добрив на вміст на врожайність і якість нових сортів картоплі. Картоплярство. К.: “Урожай”, 1987. Вип. 18. С. 40-42.

5. Патика В. П., Макаренко Н. А., Моклячук Л. І. та ін. Агроекологічна оцінка мінеральних добрив і пестицидів: монографія; за ред. В. П. Патики. К.: Основа, 2005. 300 с.

6. Технологічний регламент вирощування картоплі: рек. : Мінагрополітики України, Ін-т картоплярства УААН. Немішаєве, 2007. $15 \mathrm{c}$. 
7. Кубарева Л. С. Локальное внесение удобрений. Бюл. ВИУА. 1980. № 53. C. 13-15.

8. Картопля: сортозаміна і сортооновлення. Пропозииія. 2017. № 1. C. $126-128$.

9. Куценко В.С. Формування оптимальної густоти насаджень картоплі різного господарського призначення. Картоплярство. К., 1997. Вип. 27. С. 34-39.

\section{Information about the author:} Boyarkina L. V., Candidate (Ph.D.) of Agricultural Sciences, Senior Researcher of the Laboratory of Economics, Institute of Irrigated Agriculture of the National Academy of Agrarian Sciences of Ukraine Kherson, Naddnipryanske, 73483, Ukraine 